\title{
Impact of Organic Nutrient Management on Productivity, Nutrient Uptake and Economics of Finger millet in Groundnut (Arachis hypogaea L.) - Finger Millet (Eleusine coracana L.) Cropping System
}

\author{
M.R. Ananda*, Sharanappa and K.N. Kalyana Murthy \\ Department of Agronomy, UAS, GKVK, Bengaluru, Karnataka-560 065, India \\ *Corresponding author
}

\begin{abstract}
A B S T R A C T
A field experiment was conducted during rabi 2015 and rabi 2016 in farmers' field of Chokkahalli village of Chintamani taluk, Chikkaballapura district coming under eastern dry zone Karnataka to study the effect of bio-digested liquid manures on productivity, nutrient uptake and economics of finger millet. Significantly higher grain and straw yield

Keywords

Finger millet,

Productivity, Nutrient

Uptake, Economics,

EBDLM, Jeevamrutha,

Cow urine, Panchagavya,

Vermiwash

Article Info

Accepted:

10 October 2018

Available Online:

10 November 2018

(3787 and $5125 \mathrm{~kg} \mathrm{ha}^{-1}$ ) was recorded with the application of EBDLM @ $50 \mathrm{~kg} \mathrm{~N}$ equivalent $\mathrm{ha}^{-1}+3$ sprays of panchagavya @ $3 \%$, which was on par with application of EBDLM @ 50 kg N equivalent ha ${ }^{-1}+3$ sprays of vermiwash@3\% (3695 and 5169 kg $\left.\mathrm{ha}^{-1}\right)$. Significantly lower grain yield (3288 and4930 kg ha') was recorded with POP (50:37.5:40 Kg N: $\mathrm{P}_{2} \mathrm{O}_{5}: \mathrm{K}_{2} \mathrm{O} \mathrm{ha}^{-1}$ ) and also significantly higher uptake of nitrogen, phosphorus and potassium (129.93, 12.7 and $82.10 \mathrm{~kg} \mathrm{ha}^{-1}$, respectively) was noticed with EBDLM @ 50 kg N equivalent ha $^{-1}+3$ sprays of panchagavya@ $3 \%$ as compared to other treatments and it was on par with EBDLM @ $50 \mathrm{~kg} \mathrm{~N}$ equivalent $\mathrm{ha}^{-1}+3$ sprays of vermiwash@3\% (125.48,11.87 and 79.4 kg ha ${ }^{-1}$, respectively). However, significantly lower uptake of nutrients $\left(101.22,8.70\right.$ and $66.55 \mathrm{~kg} \mathrm{ha}^{-1}$, respectively) was noticed with POP (50:37.5:40 Kg N: $\left.\mathrm{P}_{2} \mathrm{O}_{5}: \mathrm{K}_{2} \mathrm{O} \mathrm{ha}{ }^{-1}\right)$. Further, Application of EBDLM @ $50 \mathrm{~kg} \mathrm{~N}$ equivalent $\mathrm{ha}^{-1}+3$ sprays of panchagavya @ $3 \%$ recorded higher gross returns (Rs.1,43,167 ha ${ }^{-1}$ ), net returns (Rs.1,13,671 ha ${ }^{-1}$ ) and B:C ratio (3.85) followed by EBDLM @ $50 \mathrm{~kg} \mathrm{~N}$ equivalent $\mathrm{ha}^{-1}+3$ sprays of vermiwash @ $3 \%$ (Rs.1,40,332 $\mathrm{ha}^{-1}$, Rs.1,11,146 $\mathrm{ha}^{-1}$ and 3.81, respectively). Whereas, POP (50:37.5:40 Kg N: $\mathrm{P}_{2} \mathrm{O}_{5}: \mathrm{K}_{2} \mathrm{O}$ ha $\left.^{-1}\right)$ recorded lower gross returns (Rs. 1,24,286 ha ${ }^{-1}$ ), net returns (Rs.93,725 ha-1) and B:C ratio (3.06) when compared to all other treatments.
\end{abstract}

\section{Introduction}

In recent years declining organic carbon (0.200.35 per cent) and deficit in many essential nutrients in soils is a major worry among scientists and policy makers. The physicochemical and biological properties of the soil determine the production potential of any crop either in dry lands or irrigated conditions. Keeping this in view, large quantity of organic manure is recommended for finger millet. But the use of organic manures has been continuously declining in Indian agriculture due to several reasons. Decrease in cattle population in recent years and utilization of agricultural wastes into valuable by-products 
have made the availability of organic manure in agriculture questionable both in time and quantity. Non-availability of sufficient quantity of farmyard manures drawn the attention of researchers and cultivators to utilize the on-farm wastes, green biomass of Gliricidia maculata, Pongamia pinnata etc., and ubiquitous weeds, viz. parthenium, euphotorium, lantana, calatropis, cassia etc., for biodigested liquid manure production which can substitute the farmyard manure and compost. Most of the research on finger millet was mainly concentrated on the use of FYM, compost, green manure, oil cakes etc. There is need to generate efficient organic manurial sources using on-farm available organic substrates in addition to integrated use of vermicompost, panchagavya, dashagavya, jeevamruta, beejambruta, amrutapani, sanjeevak, vermiwash, mycorrhizae culture, neem-cake/neem-seed extractants in organic farming. Further, there are evidences of enriched biodigested liquid manure use in enhancing the yields of finge rmillet, groundnut, pigeonpea and soybean (Reddy et al., 2011 and Somasundaram, 2003). There is a need to enhance nitrogen, phosphorus and potassium content of biodigested liquid manure by enriching with neem, pongamia, jatropa cake etc. and these enriched sources need to be evaluated for their effect on productivity of crops. Further, there is also need to evaluate the beneficial effects of cow urine, jeevamruta, panchagavya, vermiwash in conjunction with enriched biodigested liquid manure (EBDLM). Hence the investigation was carried out to study the efficacy of bio-digested liquid manures on the yield, nutrient uptake, balance and their economics of finger millet is needed in Alfisols of southern Karnataka.

Finger millet [Eleusine coracana (L.) Gaertn.] commonly known as ragi, is one of the major staple food crops of Karanataka particularly southern region and also an ideal food for patients suffering from diabetes. It occupies the highest area under cultivation among the small millets. The grains are rich in calcium and iron besides being rich in carbohydrate and protein. In India, it is grown in an area of 13.07 million hectares with the production of 19.29 million tonnes and the productivity is $1641 \mathrm{~kg} \mathrm{ha}^{-1}$. The state of Karnataka is the largest producer of finger millet in India. In Karnataka, finger millet is grown in an area of 7.88 lakh ha, with an annual production of 12.72 lakh tonnes and productivity of $1871 \mathrm{~kg}$ $\mathrm{ha}^{-1}$. It ranks third in area and production after rice and sorghum accounting for 58 per cent area and 45 per cent production in the state (Anon., 2013).

\section{Materials and Methods}

The field experiment was carried out during rabi 2015 and rabi 2016 in farmers' field of Chokkahalli village of Chintamani taluk, Chikkaballapura district, Karnataka to study the effect of bio-digested liquid manures on growth, nutrient uptake and economics of finger millet (Eleusine coracana). The soil is red sandy loam in texture with a bulk density of $1.43 \mathrm{~g} \mathrm{cc}^{-1}$ and water holding capacity $39.31 \%$. The soil $\mathrm{pH}$ was neutral (7.59) and the electrical conductivity was normal $(0.12$ $\left.\mathrm{dSm}^{-1}\right)$. The organic carbon content was low $(0.29 \%)$. The soil was medium in available nitrogen $\left(298.5 \mathrm{~kg} \mathrm{ha}^{-1}\right)$, phosphorus $(27.3 \mathrm{~kg}$ $\left.\mathrm{ha}^{-1}\right)$, potassium $\left(195.8 \mathrm{~kg} \mathrm{ha}^{-1}\right)$ and available sulphur $\left(21.56 \mathrm{~kg} \mathrm{ha}^{-1}\right)$. During both the years of experimentation, more rainfall was received during the first year $(917.6 \mathrm{~mm})$ of cropping season with drought during second year (417.7 $\mathrm{mm}$ ) except for beginning two months of crop period, as compared to normal rainfall (587.8 $\mathrm{mm})$. Crop was raised under rainfed condition with protective irrigation at $5 \mathrm{~cm}$ depth during the dry spell of the cropping period. There were ten treatments comprising of three types of organic liquid manures viz. jeevamrutha, enriched biodigested liquid manures 
(EBDLM) and cow urine (CU) along with foliar spray of 3\% panchagavya (PG) and 3\% vermiwash (VW) and recommended fertilizers for groundnut as detailed $\mathrm{T}_{1}$ : Jeevamrutha @ $25 \mathrm{~kg} \mathrm{~N}$ equivalent $\mathrm{ha}^{-1}, \mathrm{~T}_{2}$ : Jeevamrutha@ $25 \mathrm{~kg} \mathrm{~N}$ equivalent $\mathrm{ha}^{-1}+\mathrm{VW}$ spray @ $3 \%$, $\mathrm{T}_{3}$ : Jeevamrutha@25 kg N equivalent ha ${ }^{-1}+$ PG spray@3\%, T4: EBDLM @ $25 \mathrm{~kg} \mathrm{~N}$ equivalent $\mathrm{ha}^{-1}, \mathrm{~T}_{5}$ : EBDLM @ $25 \mathrm{~kg} \mathrm{~N}$ equivalent $\mathrm{ha}^{-1}+\mathrm{VW}$ spray @ $3 \%$, $\mathrm{T}_{6}$ :EBDLM @ $25 \mathrm{~kg} \mathrm{~N}$ equivalent ha ${ }^{-1}+\mathrm{PG}$ spray@3\%, T 1 : CU@ 25 kg N equivalent $\mathrm{ha}^{-1}, \mathrm{~T}_{8}$ : CU@25 kg N equivalent ha ${ }^{-1}+\mathrm{VW}$ spray@3\%, T9: CU@25 kg N equivalent $\mathrm{ha}^{-1}+$ PG spray@3\%, $\mathrm{T}_{10}$ : Rec. FYM $10 \mathrm{t}+$ 25:50:25 kg N:P $\mathrm{P}_{2} \mathrm{O}_{5}: \mathrm{K}_{2} \mathrm{O}$ ha $^{-1}$. The treatments were laid out in randomized complete block design with three replications. The gross plot was $3.6 \mathrm{~m} \times 3.2 \mathrm{~m}$. The bio-digested liquid manure was prepared in a 200 litre cement tank by adding $15 \mathrm{~kg}$ cow dung, 20 litre cow urine, $30 \mathrm{~kg}$ of on-farm green biomass and 100 litre water by frequent stirring. The liquid manure was incubated for 45 days, then it was enriched with 10\% Pongamia cake. While, jeevamrutha was prepared by mixing $10 \mathrm{~kg}$ local cow dung with 10 litres cow urine, $2 \mathrm{~kg}$ local jaggery, $2 \mathrm{~kg}$ bengalgram flour and handful of garden soil was added and the volume was made upto 200 litres. The plastic drum was kept in shade covering with wet gunny bag and the mixture was stirred clockwise thrice a day and incubated for 9days and the resultant jeevamrutha was used. Jeevamrutha contained $1.48,0.28$ and 0.32 per cent $\mathrm{N}, \mathrm{P}$ and $\mathrm{K}$, respectively. While, enriched biodigested liquid manure has 1.29, 0.39, 0.57 per cent $\mathrm{N}, \mathrm{P}$ and $\mathrm{K}$, respectively. The required quantity of liquid manures on nitrogen equivalent was applied to the soil. Liquid manures were applied in two equal splits at 15 and 45 days after sowing groundnut.

Panchagavya was prepared by using five products of desi cow viz. cow urine, dung, milk, curd and ghee. Vermiwash was prepared by dipping adult earth worms in luke warm water. Three per cent panchagavya and vermiwash solutions were prepared by mixing $30 \mathrm{ml}$ each panchagavya and vermiwash in $1000 \mathrm{ml}$ of water separately. Three spray of 3 $\%$ panchagavya and vermiwash was applied at 25,50 and 75 days after transplanting to finger millet as per treatments. Treatment 1 to 9 were supplied with recommended compost comprising of FYM and vermicompost at 50\% each based on $\mathrm{N}$ equivalent and treatment $\mathrm{T}_{10}$ received FYM + vermicompost at $10 \mathrm{t} \mathrm{ha}^{-1}$ two weeks before sowing and recommended dose of fertilizer 50:37.5:40 N: $\mathrm{P}_{2} \mathrm{O}_{5}: \mathrm{K}_{2} \mathrm{O} \mathrm{kg}$ $\mathrm{ha}^{-1}$ for groundnut was incorporated into the soil at the time of sowing. The nutrients were applied in the form of urea, single super phosphate and muriate of potash.

The finger millet cultivar KMR-204 was transplanted during rabi of 2015 and 2016. The spacing adopted was $30 \times 10 \mathrm{~cm}$ for groundnut. Thrips and aphids were controlled by spraying 4 per cent neem seed kernel extract twice during crop growth period of finger millet. The yield of finger millet was recorded at harvest. Further, iron, calcium and protein per cent of finger millet were computed.

\section{Results and Discussion}

\section{Grain and straw yield}

In general, the productivity of finger millet was more in the second year (2016) than in first year (2015) but response to different treatments was similar in both the years of experimentation and hence, pooled data is discussed here (Table 1). Significantly higher grain and straw yield (3787 and $5125 \mathrm{~kg} \mathrm{ha}^{-1}$ ) was recorded with the application of EBDLM @ $50 \mathrm{~kg} \mathrm{~N}$ equivalent ha ${ }^{-1}+3$ sprays of panchagavya@3\%, which was on par with application of EBDLM @ $50 \mathrm{~kg} \mathrm{~N}$ equivalent 
$\mathrm{ha}^{-1}+3$ sprays of vermiwash@ 3\% (3695 and $\left.5169 \mathrm{~kg} \mathrm{ha}^{-1}\right)$. Significantly lower grain yield (3288 and4930 $\mathrm{kg} \mathrm{ha}^{-1}$ ) was recorded with POP (50:37.5:40 Kg N: $\mathrm{P}_{2} \mathrm{O}_{5}: \mathrm{K}_{2} \mathrm{O}^{-1}{ }^{-1}$ ).

The yielding ability of a crop is the reflection of yield attributing characters like more number of productive tillers plant ${ }^{-1}$, number of fingers earhead ${ }^{-1}$, ear head length, finger length, grain yield plant $^{-1}, 100$ grain weight. Enriched biodigested liquid manures supplies secondary and micro nutrients along with $\mathrm{N}, \mathrm{P}$ and $\mathrm{K}$ and growth promoters and micronutrients content of panchagavya (Yadav and Lourduraj, 2006) which might be the reason to record higher test weight and shelling per cent. These results are in line with Somasundaram (2003) in greengram, maize and sunflower, Boomiraj (2003) in bhendi and Ravi Kumar (2009) in finger millet.

Yield is also dependent on the rate of accumulation of dry matter. The dry matter accumulation may reflect on the economic yield in view of the fact that vegetative parts of the plant serve as a source whereas grains are the sink. Dry matter production per plant differed significantly due to different nutrient sources.

Application of EBDLM @ $50 \mathrm{~kg} \mathrm{~N}$ equivalent $\mathrm{ha}^{-1}+$ PG spray @ $3 \%$ recorded significantly higher $(59.41 \mathrm{~g})$ total dry matter production plant $^{-1}$, which could be ascribed to the increase in plant size, as indicated by increase in plant height, number of tillersplant ${ }^{-1}$ and dry matter accumulation in different parts like leaf, stem and ear head, LAI and SPAD chlorophyll meter reading and their cumulative effect of all these parameters. Humic acid sources (enriched biodigested liquid manure and panchagavya) provided protoplasmic elements viz., $\mathrm{N}, \mathrm{P}$ and $\mathrm{K}$ that assisted in physiological functions of plant such as chlorophyll and protein synthesis and thereby increased in dry matter accumulation.
Similar results were reported by Reddy et al., (2010 and 2011) who carried out various field trials at Research Institute on Organic Farming at Balajigapade, Chintamani, Naganahalli and Shimoga for developing package of practices for organic finger millet production through compost and biodigester liquid manure.

At Chintamani, significantly higher grain yield $\left(2788 \mathrm{~kg} \mathrm{ha}^{-1}\right)$ of finger millet was obtained with FYM $10 \mathrm{t} \mathrm{ha}^{-1}$ + BDLM equivalent to 60 $\mathrm{kg} \mathrm{N}^{-1}$ than recommended practice (FYM $\left.7.5 \mathrm{t} \mathrm{h}^{-1}+50: 40: 25 \mathrm{~kg} \mathrm{NPK} \mathrm{ha}{ }^{-1}\right)(1388 \mathrm{~kg}$ $\mathrm{ha}^{-1}$ ). Similar yields were also obtained at Balajigapade and Chintamani with the application of $10 \mathrm{t}$ FYM and BDLM equivalent to $60 \mathrm{~kg} \mathrm{~N} \mathrm{ha}{ }^{-1}$. Besides, application of cow urine (5000 $\left.1 \mathrm{ha}^{-1}\right)$ at Navile, resulted highest grain yield (2098 kg $\left.\mathrm{ha}^{-1}\right)$ and straw yield $\left(4102 \mathrm{~kg} \mathrm{ha}^{-1}\right)$ of finger millet as compared to recommended practice (1897 and 3565, respectively).

\section{Nutrient uptake}

Data on uptake of nitrogen, phosphorus and potassium by finger millet as influenced by different liquid manures is presented in table 3. Significantly higher uptake of nitrogen, phosphorus and potassium (129.93, 12.7 and $82.10 \mathrm{~kg} \mathrm{ha}^{-1}$, respectively) was noticed with EBDLM @ $50 \mathrm{~kg} \mathrm{~N}$ equivalent ha ${ }^{-1}+3$ sprays of panchagavya@3\% as compared to other treatments and it was on par with EBDLM @ $50 \mathrm{~kg} \mathrm{~N}$ equivalent $\mathrm{ha}^{-1}+3$ sprays of vermiwash@ $3 \%$ (125.48,11.87 and 79.4 kg $\mathrm{ha}^{-1}$, respectively). However, significantly lower uptake of nutrients $(101.22,8.70$ and $66.55 \mathrm{~kg} \mathrm{ha}^{-1}$, respectively) was noticed with POP (50:37.5:40 Kg N: $\mathrm{P}_{2} \mathrm{O}_{5}: \mathrm{K}_{2} \mathrm{O}$ ha $\left.^{-1}\right)$.

The possible reason for increase in uptake of NPK may be attributed to higher nutrient availability due to enhanced microbial activity leading to mineralization and release of nutrients matching with crop demand. 


\section{Int.J.Curr.Microbiol.App.Sci (2018) 7(11): 1000-1008}

Table.1 Yield of finger millet as influenced by different liquid organic manures

\begin{tabular}{|c|c|c|c|c|c|c|}
\hline \multirow{2}{*}{ Treatments } & \multicolumn{3}{|c|}{ Grain yield (kg hat) } & \multicolumn{3}{|c|}{ Straw yield ( $\left.\mathrm{kg} \mathrm{ha} \mathrm{a}^{-1}\right)$} \\
\hline & 2015 & 2016 & Pooled & 2015 & 2016 & Pooled \\
\hline $\mathbf{T}_{1}$ & 2015 & 2016 & Pooled & 2015 & 2016 & Pooled \\
\hline $\mathbf{T}_{2}$ & 3504 & 3674 & 3589 & 5155 & 5519 & 5337 \\
\hline $\mathbf{T}_{3}$ & 3536 & 3720 & 3628 & 5099 & 5303 & 5201 \\
\hline $\mathbf{T}_{4}$ & 3589 & 3769 & 3679 & 5079 & 5320 & 5200 \\
\hline $\mathbf{T}_{5}$ & 3526 & 3717 & 3621 & 5125 & 5429 & 5277 \\
\hline $\mathrm{T}_{6}$ & 3618 & 3773 & 3695 & 5050 & 5288 & 5169 \\
\hline $\mathbf{T}_{7}$ & 3697 & 3878 & 3787 & 4946 & 5305 & 5125 \\
\hline $\mathbf{T}_{8}$ & 3316 & 3513 & 3414 & 4989 & 5248 & 5118 \\
\hline $\mathrm{T}_{9}$ & 3358 & 3585 & 3471 & 4927 & 5209 & 5068 \\
\hline $\mathbf{T}_{10}$ & 3418 & 3647 & 3532 & 4893 & 5122 & 5007 \\
\hline S. Em & 3149 & 3427 & 3288 & 4677 & 5183 & 4930 \\
\hline C.D. at $5 \%$ & 56.94 & 58.87 & 38.81 & 100.54 & 104.96 & 70.50 \\
\hline
\end{tabular}

T1: Jeevamrutha@ 25 kg N equivalent ha-1

T2: Jeevamrutha @25 kg N equivalent ha- ${ }^{1}+$ Vermi wash(VW) spray @ $3 \%$

T3: Jeevamrutha @ 25 kg N equivalent ha- ${ }^{1}+$ Panchagavya (PG) spray @ 3 \%

T4: Enriched Bio-digester Liquid Manure (EBDLM) @ $25 \mathrm{~kg} N$ equivalent ha-

T5: EBDLM @ 25 kg N equivalent ha- + + VW spray @ $3 \%$

\section{DAS: Days after sowing}

T6: EBDLM @ 25 kg N equivalent ha-1+PG spray @ $3 \%$ T7: Cow Urine (CU) @ 25 kg N equivalent ha-

T8: CU@ 25 kg N equivalent ha-1+VW spray @ $3 \%$ T9: CU@ 25 kg N equivalent ha- ${ }^{1}+$ PG spray @ $3 \%$ T10: Rec. POP. 25:50:25 kg NPK ha- ${ }^{1}$ 
Table.2 Uptake of NPK by finger millet as influenced by different liquid organic manures

\begin{tabular}{|c|c|c|c|c|c|c|c|c|c|}
\hline \multirow[t]{2}{*}{ Treatments } & \multicolumn{3}{|c|}{$\mathbf{N}\left(\mathrm{kg} \mathrm{ha}^{-1}\right)$} & \multicolumn{3}{|c|}{$\mathbf{P}\left(\mathrm{kg} \mathrm{ha}^{-1}\right)$} & \multicolumn{3}{|c|}{$\mathrm{K}\left(\mathrm{kg} \mathrm{ha}^{-1}\right)$} \\
\hline & 2015 & 2016 & Pooled & 2015 & 2016 & Pooled & 2015 & 2016 & Pooled \\
\hline $\mathrm{T}_{1}$ & 112.50 & 114.80 & 113.65 & 10.20 & 11.40 & 10.80 & 73.23 & 74.80 & 74.02 \\
\hline$\overline{T_{2}}$ & 118.70 & 120.67 & 119.68 & 10.80 & 11.70 & 11.25 & 74.70 & 76.40 & 75.55 \\
\hline $\mathbf{T}_{\mathbf{3}}$ & 123.60 & 124.80 & 124.20 & 11.50 & 12.30 & 11.90 & 76.70 & 78.30 & 77.50 \\
\hline$\overline{T_{4}}$ & 121.33 & 124.20 & 122.77 & 11.30 & 12.20 & 11.75 & 76.60 & 80.20 & 78.40 \\
\hline $\mathbf{T}_{\mathbf{5}}$ & 124.37 & 126.60 & 125.48 & 11.17 & 12.57 & 11.87 & 77.20 & 81.60 & 79.40 \\
\hline$\overline{T_{6}}$ & 128.47 & 131.40 & 129.93 & 12.20 & 13.20 & 12.70 & 79.40 & 84.80 & 82.10 \\
\hline$\overline{T_{7}}$ & 101.30 & 102.60 & 101.95 & 8.80 & 9.20 & 9.00 & 68.83 & 68.90 & 68.87 \\
\hline $\mathbf{T}_{8}$ & 103.50 & 104.60 & 104.05 & 9.20 & 9.80 & 9.50 & 69.30 & 70.87 & 70.08 \\
\hline$T_{9}$ & 108.40 & 110.30 & 109.35 & 9.87 & 10.40 & 10.13 & 70.60 & 72.40 & 71.50 \\
\hline$\overline{T_{10}}$ & 98.50 & 103.93 & 101.22 & 8.10 & 9.30 & 8.70 & 65.80 & 67.30 & 66.55 \\
\hline S. Em \pm & 3.88 & 3.99 & 2.60 & 0.82 & 0.64 & 0.48 & 3.32 & 2.72 & 2.40 \\
\hline C.D. at $5 \%$ & 11.54 & 11.85 & 7.73 & 2.44 & 1.91 & 1.42 & 9.86 & 8.09 & 7.12 \\
\hline \multicolumn{6}{|c|}{$\begin{array}{l}\text { T1: Jeevamrutha @ } 25 \text { kg N equivalent ha- }{ }^{1} \\
\text { T2: Jeevamrutha @ } 25 \text { kg N equivalent ha- }{ }^{1}+\text { Vermi wash(VW) spray } \\
\text { @ } 3 \% \\
\text { T3: Jeevamrutha @ } 25 \text { kg N equivalent ha- }{ }^{1}+\text { Panchagavya (PG) } \\
\text { spray @ } 3 \% \\
\text { T4: Enriched Bio-digester Liquid Manure (EBDLM) @ } 25 \text { kg N } \\
\text { equivalent ha- }{ }^{1} \\
\text { T5: EBDLM @ } 25 \text { kg N equivalent ha- }{ }^{+}+\text {VW spray @ } 3 \%\end{array}$} & \multicolumn{4}{|c|}{$\begin{array}{l}\text { T6: EBDLM @ } 25 \text { kg N equivalent ha- }{ }^{1}+\text { PG spray } \\
\text { @ } 3 \% \\
\text { T7: Cow Urine (CU) @ } 25 \text { kg N equivalent ha- }{ }^{1} \\
\text { T8: CU@ } 25 \text { kg N equivalent ha- }{ }^{1}+\text { VW spray @ } 3 \\
\% \\
\text { T9: CU@ } 25 \text { kg N equivalent ha- }{ }^{1}+\text { PG spray @ } 3 \\
\% \\
\text { T10: Rec. POP. } 25: 50: 25 \text { kg NPK ha- }{ }^{1}\end{array}$} \\
\hline
\end{tabular}


Table.3 Economics of finger millet as influenced by different liquid organic manures

\begin{tabular}{|c|c|c|c|c|c|c|c|c|c|c|c|c|}
\hline \multirow[t]{2}{*}{ Treatments } & \multicolumn{3}{|c|}{ Cost of Cultivation (Rs. ha ${ }^{-1}$ ) } & \multicolumn{3}{|c|}{ Gross Returns (Rs. ha ${ }^{-1}$ ) } & \multicolumn{3}{|c|}{ Net Returns (Rs.ha ${ }^{-1}$ ) } & \multicolumn{3}{|c|}{ B:C ratio } \\
\hline & 2015 & 2016 & Pooled & 2015 & 2016 & Pooled & 2015 & 2016 & Pooled & 2015 & 2016 & Pooled \\
\hline $\mathbf{T}_{1}$ & 28439 & 28809 & 28624 & 132451 & 138877 & 135664 & 104012 & 110068 & 107040 & 3.66 & 3.82 & 3.74 \\
\hline $\mathbf{T}_{2}$ & 28786 & 28974 & 28880 & 133660 & 140767 & 137214 & 104874 & 111793 & 108334 & 3.64 & 3.86 & 3.75 \\
\hline $\mathbf{T}_{\mathbf{3}}$ & 29069 & 29249 & 29159 & 135664 & 142468 & 139066 & 106595 & 113219 & 109907 & 3.67 & 3.87 & 3.77 \\
\hline $\mathbf{T}_{4}$ & 28571 & 28762 & 28666 & 133282 & 140502 & 136892 & 104711 & 111740 & 108226 & 3.66 & 3.89 & 3.77 \\
\hline $\mathbf{T}_{5}$ & 29092 & 29281 & 29186 & 136760 & 143904 & 140332 & 107668 & 114623 & 111146 & 3.70 & 3.91 & 3.81 \\
\hline $\mathrm{T}_{6}$ & 29406 & 29587 & 29496 & 139746 & 146588 & 143167 & 110340 & 117001 & 113671 & 3.75 & 3.95 & 3.85 \\
\hline $\mathbf{T}_{7}$ & 28274 & 28471 & 28372 & 125344 & 132791 & 129068 & 97070 & 104320 & 100695 & 3.43 & 3.66 & 3.55 \\
\hline $\mathbf{T}_{8}$ & 28752 & 28979 & 28865 & 126932 & 135513 & 131222 & 98180 & 106534 & 102357 & 3.41 & 3.68 & 3.55 \\
\hline $\mathbf{T}_{9}$ & 29119 & 29349 & 29234 & 129200 & 137894 & 133547 & 100081 & 108545 & 104313 & 3.44 & 3.70 & 3.57 \\
\hline $\mathbf{T}_{10}$ & 30423 & 30701 & 30562 & 119032 & 129540 & 124286 & 88609 & 98840 & 93725 & 2.91 & 3.22 & 3.06 \\
\hline
\end{tabular}

T1: Jeevamrutha @ 25 kg N equivalent ha- ${ }^{1}$

T2: Jeevamrutha @25 kg N equivalent ha- ${ }^{1}+$ Vermi wash (VW) spray @ $3 \%$

T3: Jeevamrutha @ 25 kg N equivalent ha- ${ }^{1}+$ Panchagavya (PG) spray @ $3 \%$

T4: Enriched Bio-digester Liquid Manure (EBDLM) @ 25 kg N equivalent ha- ${ }^{1}$

T5: EBDLM @ 25 kg N equivalent ha- + VW spray @ $3 \%$

DAS: Days after sowing
T6: EBDLM @ 25 kg N equivalent ha-+ PG spray @ 3\% T7: Cow Urine (CU) @ 25 kg N equivalent ha- ${ }^{1}$

T8: CU@ 25 kg N equivalent ha- ${ }^{1}+$ VW spray @ $3 \%$ T9: CU@ 25 kg N equivalent ha-1+PG spray @ $3 \%$ T10: Rec. POP. 25:50:25 kg NPK ha- ${ }^{1}$

NS: Non significant 
Combined application of FYM + vermicompost and EBDLM acted as slow release nutrient sources. Nutrient uptake by crop mainly depends on both supply of nutrients and rate of uptake by the crop. Slow and steady release of nutrients from FYM and BDLM enriched with poultry manure or neem cake matched with crop demand. These results corroborate with the findings of Suresh Naik (2011) who found that the application of FYM $12.5 \mathrm{t}+$ BDLME at 150 $\mathrm{kg} \mathrm{N}$ ha $^{-1}$ had significantly resulted in the highest nitrogen uptake of maize $(184.5 \mathrm{~kg}$ $\left.\mathrm{ha}^{-1}\right)$. Besides, Manjunath (2010) also reported similar results on maize from Mandya.

Nitrogen uptake was significantly higher (137.9 $\mathrm{kg} \mathrm{ha}^{-1}$ ) by finger millet with the application of FYM $10 \mathrm{t} \mathrm{ha}^{-1}+$ BDLM enriched with poultry manure and rock phosphate equivalent to $60 \mathrm{~kg}$ $\mathrm{N}$ ha $^{-1}$ and FYM $10 \mathrm{t}+$ BDLM enriched with neem cake and rock phosphate equivalent to 60 $\mathrm{kg} \mathrm{N} \mathrm{ha}{ }^{-1}$ as reported by Sudheendra Saunshi (2012).

However, the increase in uptake of nutrients with foliar spray of panchagavya was ascribed to increased biological efficiency of crop plants and creating greater source and sink in the plant system (Boomathi et al., 2005) that might have contributed for greater absorption of the nutrients. There was increase in leaf area index in the treatments which received sprays of 3 per cent panchagavya facilitating increased photosynthetic efficiency of plants leading to increased uptake of nutrients.

\section{Economics}

The acceptance of any generated technology by the farmers ultimately depends on the profits realized upon cost incurred in the production. Among the different indicators of monitory efficiency, the net returns have a greater impact on the practical utility and acceptance of technology. Data on the effect of different liquid manures and organic source of nutrients on economic parameters viz., cost of cultivation, gross returns, net returns and benefit cost ratio are presented in table 3 .
The total cost of cultivation was higher (Rs. $\left.30,562 \mathrm{ha}^{-1}\right)$ with POP $(50: 37.5: 40 \mathrm{Kg} \mathrm{N}$ : $\mathrm{P}_{2} \mathrm{O}_{5}: \mathrm{K}_{2} \mathrm{O}$ ha $^{-1}$ ) as compared to other treatments. Whereas, in case of CU @ $50 \mathrm{~kg} \mathrm{~N}$ equivalent $\mathrm{ha}^{-1}$ the cost of cultivation was lower (Rs.28,372 $\left.\mathrm{ha}^{-1}\right)$.

Application of EBDLM @ $50 \mathrm{~kg} \mathrm{~N}$ equivalent $\mathrm{ha}^{-1}+3$ sprays of panchagavya @3\% recorded higher gross returns (Rs.1,43,167 $\mathrm{ha}^{-1}$ ) and net returns (Rs.1,13,671 $\mathrm{ha}^{-1}$ ) followed by EBDLM @ $50 \mathrm{~kg} \mathrm{~N}$ equivalent $\mathrm{ha}^{-1}+3$ sprays of vermiwash at $3 \%$ (Rs.1,40,332 $\mathrm{ha}^{-1}$ ) and (Rs.1,11,146 $\mathrm{ha}^{-1}$ ), respectively.

Whereas, POP (50:37.5:40 Kg N: $\mathrm{P}_{2} \mathrm{O}_{5}: \mathrm{K}_{2} \mathrm{O}$ $\mathrm{ha}^{-1}$ ) recorded lower gross returns (Rs. 1,24,286 $\mathrm{ha}^{-1}$ ) and net returns (Rs.93,725 ha $\mathrm{ha}^{-1}$ when compared to all other treatments.

The Benefit: Cost ratio was higher with EBDLM @ 50 kg N equivalent ha ${ }^{-1}+3$ sprays of panchagavya@ $3 \%$ (3.85) followed by EBDLM @ $50 \mathrm{~kg} \mathrm{~N}$ equivalent $\mathrm{ha}^{-1}+3$ sprays of vermiwash@ $3 \%$ (3.81). While, lower Benefit: Cost ratio (3.06) was recorded with POP (50:37.5:40 Kg N: $\mathrm{P}_{2} \mathrm{O}_{5}: \mathrm{K}_{2} \mathrm{O}$ ha $^{-1}$ ). Reddy et al., (2010) at ARS, Balajigapade obtained higher $\mathrm{B} C$ ratio of 1.66 in finger millet with the application of FYM $10 \mathrm{t} \mathrm{ha}^{-1}+$ biodigester liquid manure equivalent to $60 \mathrm{~kg} \mathrm{~N} \mathrm{ha}^{-1}$.

Similar results of higher gross returns, net returns and $\mathrm{B}$ : $\mathrm{C}$ ratio were obtained with the application of EBDLM and panchagavya in finger millet by Govindappa (2003), Sudheendra Saunshi (2012) and Latha and Sharanappa (2014b) in ground nut-onion sequence.

It can be concluded from the study that the application of enriched liquid organic manure or jeevamrtha 15 and 45 days after sowing for finger millet equivalent to 100 per cent recommended dose of nitrogen with foliar spray of panchagavya or vermiwash at 3 per cent on 25, 50 and 75 DAS is the best option for higher productivity of finger millet and economics besides improving other parameters. 


\section{References}

Annonymous, 2013, Directorate of Economics and Statistics, Govt. of Karnataka.

Boomathi, N., Suganya Kanna, S. and Jeyarani, S., 2005, Panchagavya - A gift from our mother's nature. Agrobios Newslet., 4(3): 20-21.

Boomiraj, G.S., 2003, Effect of panchagavya foliar spray on fruit yield and quality of okra. Ind. J. Agron., 45(2): 12-18.

Govindappa, M., 2003, Efficacy of different organic manures and inorganic fertilizer on growth and yield of rainfed finger millet [Eleusine coracana (L.) Gaertn.] M.Sc. (Agri.) Thesis, Univ. Agric. Sci., Bangalore.

Latha, H.S. and Sharanappa, 2014b, Production potential, nutrient -use efficiency and economics of groundnut (Arachis hypogaea) - Onion (Allium cepa) cropping system under organic nutrient management Indian J. Agron., 59(1):5964.

Manjunatha, R., 2010, Effect of different combinations of organic nutrient sources on growth and yield of maize (Zea mays L.) under Cauvery command area. M.Sc. (Agri.) Thesis, Univ. of Agril. Sci., Bangalore.

Ravi Kumar, H.S., 2009, Comparative performance of integrated organic nutrient supply systems on growth and yield of groundnut (Arachis hypogaea L.). M.Sc. (Agri.) Thesis, Univ. Agril. Sci., Bangalore.

Reddy, V. C. and Shivanandam, V. N., 2010. Developing organic package of practice for yield maximization of rainfed finger millet. Ann. Prog. Report, Research Institute on Organic Farming, Univ. Agric. Sci., Bangalore. pp. 26-31.

Reddy, V.C., Jayaram Reddy, M., Shivanandam, V.N., Yogananda, S.B., Govindaraju, C. and Jagadeesh, B. R., 2011, Developing package of practices for production of finger millet through compost and bio digester liquid manure. Annual Progress Report, Research Institute on Organic Farming, University of Agricultural Sciences, Bengaluru Karnataka, India. pp. 13-21, 23-26, 30-34 and 47-48.

Somasundaram, E., 2003, Evaluation of organic sources of nutrients and panchagavya spray on the growth and productivity of maize-sunflower-greengram system. Thesis submitted to Tamil Nadu Agricultural University, Coimbatore for award of $P h . D$. degree.

Sudheendra Saunshi, Reddy, V. C., Mallikarjun and Rajesh Rawal, 2014, Influence of enriched bio-digester liquid manure on growth and yield of finger millet. The Bioscan. 9(2): 613-616.

Suresh Naik, 2011, Effect of farmyard manure and bio digester liquid manure on growth and yield of rainfed maize (Zea mays). M.Sc. (Agri.) Thesis, Univ. Agril. Sci., Bangalore.

Yadav, B. K. and Lourduraj, C. A., 2006, Effect of organic manures and panchagavya spray on yield attributes, yield and economics of rice (Oryza sativa L.). Crop Research. 32(1): 1-5.

\section{How to cite this article:}

Ananda, M.R., Sharanappa and Kalyana Murthy, K.N. 2018. Impact of Organic Nutrient Management on Productivity, Nutrient Uptake and Economics of Finger millet in Groundnut (Arachis hypogaea L.) - Finger Millet (Eleusine coracana L.) Cropping System. Int.J.Curr.Microbiol.App.Sci. 7(11): 1000-1008. doi: https://doi.org/10.20546/ijcmas.2018.711.115 